\title{
Pengaruh Model Pembelajaran Quantum Teaching Terhadap Hasil Belajar Kognitif Peserta Didik Ditinjau dari Kecerdasan Majemuk
}

\author{
Ratna Pramudita 1 \\ PAUD Islam Al-Amin Bandar Lampung, Jalan cendana , Rawalaut, Bandar Lampung 35121, \\ Indonesia \\ *Corresponding Author. E-mail: Ratnapramudita27@gmail.com
}

Received : 28-05-2018; Revised : 30-05-2018; Accepted : 31-05-2018

\begin{abstract}
Abstrak
Melihat pengaruh model pembelajaran quantum teaching terhadap hasil belajar kognitif peserta didik ditinjau dari kecerdasan majemuk merupakan suatu tujuan dari penelitian ini. Agar tujuan dapat tercapai maka jenis penelitian yang digunakan adalah Quasy Experiment. Adapun teknik yang digunakan dalam pengambilan sampel yang digunakan adalah tehnik acak kelas. Teknik pengumpulan data yang digunakan adalah tes, wawancara, observasi dan angket.Uji hipotesis yang digunakan adalah uji Analisis variansi dua jalan (Anava 2 Jalan). Namun sebelum hipotes diuji, telah dilakukan uji prasyarat terlebih dahulu yaitu uji Validitas, tingkat kesukaran, daya beda, reabilitas, normalitas dan uji homogenitas. Berdasarkan hasil uji yang telah dianalisis didapatkan bahwa terdapat pengaruh hasil belajar kognitif peserta didik dengan menggunakan model quantum teaching. Selanjutnya terdapat perbedaan hasil belajar kognitif antara peserta didik yang memiliki kecerdasan logis-matematis dengan peserta didik yang memiliki kecerdasan interpersonaldan naturalis.Selanjutnya Tidak terdapat interaksi antara model pembelajaran dan kecerdasan peserta didik logis-matematis, interpersonal, dan naturalis terhadap hasil belajar kognitif peserta didik.
\end{abstract}

Kata Kunci :Hasil belajar kognitif; kecerdasan majemuk; quantum teaching

\begin{abstract}
Seeing the influence of quantum teaching model on learning outcomes of cognitive learners in terms of multiple intelligences is an objective of this study. For the purpose can be achieved then the type of research used is Quasy Experiment. The technique used in sampling used is a random technique class. Data collection techniques used are tests, interviews, observations, and questionnaires. The test hypothesis used is the test of variance analysis of two streets (Anava 2 Road). However, before the hypothesis is tested, preliminary tests have been performed, namely Validity test, difficulty level, differentiation, reliability, normality and homogeneity test. Based on test results that have been analyzed found that there is the influence of cognitive learning outcomes of learners using quantum teaching model. Furthermore, there are differences in cognitive learning outcomes between learners who have logical-mathematical intelligence with learners who have interpersonal and naturalist intelligence. Further, There is no interaction between learning models and intelligence of logical-mathematical, interpersonal, and naturalist learners to cognitive learning outcomes of learners.
\end{abstract}

Keywords: Coqnitive learning outcomes; multiple intelligences; quantum teaching

\section{PENDAHULUAN}

Mempelajari matematika tidak hanya memahami konsepnya saja atau prosedurnya saja, akan tetapi banyak hal yang dapat muncul dari hasil proses pembelajaran matematika (Widyastuti, 2015). Menyangkut dengan penjelasan tersebut maka perlu suatu pembelajaran yang terstruktur dalam pembelajaran matematika dengan tujuan meningkatkan hasil belajarkognitif peserta didik dalam pembelajaran matematika itu sendiri. Seperti yang telah dijelaskan oleh Lamba (2016) untuk meningkatkan mutu 


\section{Desimal, 1 (2), 2018 - 246}

Ratna Pramudita

pendidikan secara umum maka diperlukan perubahan pola pikir yang berkaitan erat dengan hasil belajar kognitif peserta didik sebagai landasan pembelajaran. Namun dalam beberapa penelitian mengungkapkan bahwa hasil belajar peserta didik masih memberikan kabar buruk yaitu masih dalam kategori rendah (Bahri, 2010); Febriyanto, 2011); Gani \& Syahrun, 2015; Ningsih, Misdalina, \& Marhamah, 2017).

Begitu juga yang terjadi di SMPN 11 Bandar Lampung, berdasarkan dokumen hasil hasil belajar UAS semester ganjil peserta didik tahun 2016/2017 masih menunjukkan memperoleh nilai dibawah rata-rata nilai KKM.Berdasarkan hasil wawancara dengan guru di SMPN 11 Bandar Lampung dari 5 kelas hasil ulangan semester ganjil siswa masih $40 \%$ belum mencapai kkm.Rendahnya hasil belajar siswa ini tentunya harus patut harus ada evaluasi tersendiri bagi para guru-guru khususnya dalam pembelajaran matematika agar tujuan pembelajaran dapat tercapai. Menurut Amiluddin \& Sugiman (2016) dan Mujib(2016) dalam penelitiannya bertujuan untuk mengetahui pengaruhmodel pembelajaran terhadap hasil belajar peserta didik. Diduga model pembelajaran Quantum Teachingmampu meningkatkan hasil belajar kognitifpeserta didik.Dugaan ini didukung oleh beberapa penelitian, berdasarkan penelitian Prabawanti (2015) dalam penelitiannya bertujuan untuk mengetahui pengaruh model Quantum Teaching terhadappeningkatkan hasil belajar siswa dibandingkan dengan metode ceramah. Keterbaharuan dalam penelitian ini adalah hasil belajar kognitifsiswa yang ditinjau dari kecerdasan majemuk. Selain itu Siregar \& Juliani (2014) dalam penelitianya mengungkapkan tujuan dari dilakukakannya penelitian tersebut ialah untuk mencari keterkaitan antara model pembelajaran quantum teaching dengan hasil belajar siswa pada materi zat dan wujudnya. Keterbaharuan atau perbedaan dalam penelitian ini dilakukan untuk mata pelajaran matematika sesuai dengan saran yang tercancum bahwa direkomendasikan menggunakan model Quantum Teaching ini pada mata pelajaran lain.

Menurut Danaryanti \& Julianti (2014) dalam penelitiannya bertujuan mengetahui pengaruh model pembelajaran quantum teaching terhadap kemampuan komunikasi matematis dan hasil belajar siswa kelas XI SMAN 1 Banjarmasin. Keterbaruan dari penelitian ini dilakukan di SMPN11 Bandar Lampung. Selain itu menurut Winaya (2016) dalam penelitiannya bertujuan untuk mengetahui pengaruh model pembelajaran quantum teaching dengan langkah-langkah TANDUR terhadap keterampilan proses pada materi sel (IPA). Keterbaruan atau perbedaan pada penelitian ini ialah peneliti menggunakan model pembelajaran quantum teaching terhadap hasil belajar dan maata pelajaran yang digunakan matematika materi segiempat.

Menurut Winaya (2016) dalam penelitiannya memiliki tujuan mengetahui efektivitas model quantum teaching terhadap hasil belajar ditinjau keterampilan berpikir kritis pada pembelajaran IPA dikelas $\mathrm{V}$ SD. Keterbaruan atau perbedaan pada penelitian ini peneliti meninjau dari kecerdasan majemuk. Selain itu juga menurut Mohiddin (2016) dalam penelitiannya bertujuan untuk mengetahui pengaruh model pembelajaran quantum teaching dan kemampuan berpikir matematis terhadap hasil belajar siswa. Perbedaan dalam penelitian ini yaitu peneliti hanya menggunakan model pembelajaran yang sama tetapi tidak menggunakan kemampuan berpikir kritis matematis.

Quantum Teachingmerupakan salah satu metode belajar yang bisa digunakan 
oleh siapa saja karena memberikan gambaran untuk mendalami apa saja dengan cara mantap dan berkesan. Caranya, seorang pembelajaran harus mengetahui terlebih dahulu gaya belajar, gaya berpikir, dan situasi dirinya. Dengan begitu, pembelajaranakan dengan cepat mendalami sesuatu. Dengan Quantum Teaching, segalanya dapat dengan mudah, cepat, dan mantap dikaji dan didalami dengan suasana yang menyenangkan (Sari, Susilowati, \& Ridlo, 2013; Sudarman \& Vahlia, 2016).

Hasil belajar merupakan salah satu faktor yang sangat penting karna hasil belajar yang dicapai peserta didik merupakan alat untuk mengukur sejauh mana peserta didik menguasai materi pelajaran yang diajarkan (Nurliani, Subarjah, \& Sujana, 2016)

Berdasarkan penelitian Fadila (2015) dalam penelitiannya meninjau tentang kecerdasan majemuk terhadapPrestasi belajar siswa dengan kecerdasan logis matematika, kecerdasan kinestetik dan interpersonal.Keterbaruan dari penelitian ini meninjau kecerdasan majemuk terhadap hasil belajar.Kecerdasan yang digunakan ialah kecerdasan logismatematis, interpersonal dan naturalis. Selain itu bedasarkan penelitian Husni, Kamaluddin, \& Kade (2014) dalam penelitiannya bertujuan untuk mengetahui hubungan kecerdasan majemuk dengan hasil belajar kognitif pada mata pelajaran IPA. Keterbaruan dari penelitian ini ialah mengetahui pengaruh dari kecerdasan majemuk terhadap hasil belajar kognitif pada mata pelajaran matematika. Selain itu menurut Sholikhah \& Budiyono (2014) dalam penelitiannya untuk mengetahui pengaruh dari model pembelajaran kooperatif tipe group investigation dan NHT pada materi garis singgung lingkaran ditinjau dari kecerdasan majemuk. Keterbaruan atau pebedaan dalam penelitian ini ialah model pembelajaran yang digunakan, penulis menggunakan model pembelajaran quantum teaching dengan materi segiempat kelas VII. Selanjutnya penelitian yang dilakukan Hariyati, Mardiyana, \& Usodo (2013) dalam penelitiannya bertujuan mengetahui pengaruh model pembelajaran kooperatif tipe (Team Assisted Individualization) TAI dan (Problem Based Learning) PBL pada prestasi belajar matematika ditinjau dari multiple intelligences. Perbedaan atau keterbaruan pada penelitian ini ialah model pembelajaran yang digunakan terhadap hasil belajar kognitif peserta didik. Sehingga penulis tertarik melakukan penelitian untuk melihat pengaruh model quantum teaching terhadap hasil belajar kognitif peserta didik ditinjau dari kecerdasan majemuk.

Tujuan dari penelitian yang dilakukan oleh peneliti ialahMengetahui pengaruh model pembelajaran quantum teaching terhadap hasil belajar kognitif peserta didik, mengetahui pengaruh kecerdasan majemuk terhadap hasil belajar kognitif, mengetahui interaksi antara model pembelajaran dan kecerdasan majemuk terhadap hasil belajar peserta didik.

\section{METODE PENELITIAN}

Dalam penelitian ini, penulis menggunakan metode penelitian eksperimen karena penulis akan mencariperbedaan treatment (perlakuan) tertentu. Desain penelitian yang akan digunakan adalah posttest-only control design dan rancangan penelitian faktorial $2 \times 3$ yang dapat digambarkan sebagai berikut: 
Desimal, 1 (2), 2018 - 248

Ratna Pramudita

\begin{tabular}{|c|c|c|c|}
\hline \multirow{2}{*}{$\begin{array}{l}\text { HasilBelajar } \\
\text { Model } \\
\text { Pembelajaran }\end{array}$} & \multicolumn{3}{|c|}{ KecerdasanMajemuk } \\
\hline & $\begin{array}{c}\text { KecerdasanMatematis } \\
\text { Logis (ML) }\end{array}$ & $\begin{array}{l}\text { Kecerdasan } \\
\text { Interpersonal } \\
\text { (IP) }\end{array}$ & $\begin{array}{l}\text { KecerdasanNaturalis } \\
\text { (Lingkungan) }\end{array}$ \\
\hline $\begin{array}{l}\text { Quantum } \\
\text { Teaching }\left(\mathrm{A}_{1}\right)\end{array}$ & $\mathrm{A}_{1} \mathrm{~B}_{1}$ & $\mathrm{~A}_{1} \mathrm{~B}_{2}$ & $A_{1} B_{3}$ \\
\hline Konvensional $\left(\mathrm{A}_{2}\right)$ & $\mathrm{A}_{2} \mathrm{~B}_{1}$ & $\mathrm{~A}_{2} \mathrm{~B}_{2}$ & $\mathrm{~A}_{2} \mathrm{~B}_{3}$ \\
\hline
\end{tabular}

Keterangan :

$\mathrm{A}_{1} \mathrm{~B}_{1}$ :model pembelajaran Quantum Teaching dengan kecerdasan Matematis-Logis (ML)

$\mathrm{A}_{1} \mathrm{~B}_{2}$ :model pembelajaran Quantum Teaching dengan kecerdasan Interpersonal.

$\mathrm{A}_{1} \mathrm{~B}_{3}$ :model pembelajaran Quantum Teaching dengan kecerdasan Naturalis (Lingkungan)

Jenis metode eksperimen yang digunakan adalah Quasy Experimental Design. Penelitian ini teknik sampling yang digunakan adalah teknik acak kelas (Random Sampling)yaitu terdiri dari kelas eksperiment (model quantum teaching \& pendekatan kontekstual) dan kelas kontrol (model ceramah).Teknik analisis data dalam pengujian hipotesis adalah sebagai berikut (Novalia \& Syazali, 2014):

1. Uji normalitas

Uji normalitas dengan menggunakan metode Lilifors, dengan Uji statistik:

$$
\begin{gathered}
L=\operatorname{Max}\left|F\left(z_{i}\right)-S\left(z_{i}\right)\right| \text { dimana } \\
Z_{i}=\frac{X_{i}-\bar{x}}{S}
\end{gathered}
$$

Denga Keputusanuji:

$H_{0}$ diterima jika nilai statistik uji jatuh diluar daerah kritik

Kesimpulan

$\mathrm{H}_{0}$ : data mengikuti sebaran normal

$\mathrm{H}_{1}$ : data tidak mengikuti sebaran normal

Dengan Kriteria uji

Dengan taraf signifikan $\alpha=0,05$

2. Uji Homogenitas

Uji homogenitas dengan menggunakan uji bartlettt. rumus yang digunakan dalam mencari homogenintas adalah sebagai berikut:

$$
x^{2}=\frac{2.203}{c}\left(f \log R K G-\sum f_{i} \log {s_{i}}^{2}\right)
$$

Dengan : $x^{2} \sim x^{2}(K-1)$

$\mathrm{K}$ : Banyaknya populasi :banyak nya sampel

$\mathrm{N}$ : Banyaknyaseluruhnilai

$n_{j}$ : Banyaknya nilai(ukuran) sampai ke $\mathrm{j}$

ukuran sampai ke-j

$f_{j}=n_{j}-1$ : derajat kebebasan untuk $s_{i}{ }^{2} ; j=1,2,3 \ldots, k$ :

$F=N-k=\sum_{j-1}^{k} f_{j}$ : derajat kebebasan untuk RKG

$C=1+\frac{1}{3(K-1)}\left(\sum \frac{1}{f_{j}}-\frac{1}{f}\right) \mathrm{ss}$

$\mathrm{RKG}$ : rerata kuadrat galat $=\frac{\sum s s_{j}}{\sum f_{j}}$

$$
s s_{j}=\sum s_{i}{ }^{2}-\frac{\sum\left(s_{j}\right)^{2}}{n_{j}}=\left(n_{j}-1\right) s_{j}{ }^{2}
$$

Daerah kritis

$$
D K=\left\{/{ }^{2} \mid x^{2}>x^{2} a, k-1\right.
$$

jumlah berapa $\alpha$ dan $k-1$ nilai $x^{2}{ }_{a, k-1}$ dapat dilihat pada tabel chi kuadrat dengan derajat kebebasan $(k-1)$

Keputusan Uji

$H_{0}$ : ditolak jika harga statistik $x^{2}$, yakni $x^{2}{ }_{\text {hitung }}>x_{a, k-1}^{2}$ berarti variansi dari populasi tidak homogen.

\section{Uji Hipotesis}

a. Uji Anava Dua Arah

Uji anava dua arah ini digunakan untuk menjawab rumusan masalah yang ke $1,2,3$. Pengujian hipotesis ini akan menggunakan analisis variansi dua jalan sel tak sama dengan model sebagai berikut:

$$
X_{i j k}=\mu+\alpha_{i}+\beta_{j}+\alpha \beta_{i j}+\epsilon_{i j k}
$$

Dengan :

$X_{i j k}$ :data amatan ke-i dalam kolom ke-j

$\mu$ :rerata dari seluruh data amatan

(rerata besar, grand mean)

$\alpha_{i}$ :efek baris ke-i pada variabel terikat,

dengan $\mathrm{i}=1,2$ 
$\beta_{j} \quad$ :efek baris ke-j pada variabel

terikat, dengan $\mathrm{j}=1,2,3$

$\alpha \beta_{i j}$ : kombinasi efek bari ke-i dan kolom

ke-j pada variabel terikat

$\epsilon_{i j k}$ :deviasi amatan terhadap rataan

populasinya $\quad\left(\pi_{i j}\right) \quad$ yang

berdistribusi normal dengan

rataan 0 , deviasi amatan terhadap

rataan populasi juga disebut eror (galat).

$i \quad: 1,2$ yaitu (1: Model pembelajaran Quantum Teaching), (2 : Model Pembelajaran Konvensional)

\section{$j: 1,2,3$ yaitu: (1:Kecerdasan}

Matematika Logis), (2 :

Kecerdasan Interpersonal),(3:

Kecerdasan Naturalis)

Dengan hipotesis yang digunakan adalah :

1) $H_{0 A}: \alpha_{i}=0$ ountuk i $=1,2$ (tidak ada pengaruh antara model pembelajaran Quantum Teaching terhadap hasil belajar)

$H_{1 A}: a_{i} \neq 0$ (ada pengaruh antara model pembelajaran Quantum Teaching terhadap hasil belajar)
2) $\quad H_{0 B}: \beta_{j}=$ 0untuk $\mathrm{j}=1,2,3$ (tidak ada perbedaan antar kolom terhadap variabel terikat) $H_{1 B}: \beta_{j} \neq 0$ untuk $j=1,2,3$ paling sedikit satu harga $\mathrm{j}$ (ada perbedaan efek antar kolom terhadap variabel terikat.

3) $H_{0 A B}: a \beta_{i j}=0$ untuk semua $i j$ dengan $i=1,2$ dan $j=1,2,3$ (tidak ada interaksi baris dan antar kolom terhadap variabel terikat) $H_{1 A B}: a \beta_{i j} \neq 0$ paling sedikit ada satu pasang $(i j)$ ( ada interaksi baris dan antar kolom terhadap variabel terikat).

\section{HASIL PENELITIAN DAN PEMBAHASAN}

Setelah data hasil belajar kognitif peserta didik terkumpul baik dari kelas eksperimen maupun dari kelas kontrol, diperoleh nilai tertinggi $\left(X_{\text {maks }}\right)$ pada kelas eksperimen data kelas kontrol dan dicari ukuran tendensi sentral meliputi rataan $(\bar{x})$, median $\left(\mathrm{M}_{\mathrm{e}}\right)$, modus $\left(\mathrm{M}_{\mathrm{o}}\right)$ serta ukuran variansi kelompok meliputi jangkauan (R) dan simpangan baku (s) yang dapat dirangkum pada tabel seperti berikut ini.

Tabel 2. Deskripsi Data Amatan Nilai Hasil Belajar Kognitif Peserta Didik Kelas Eksperimen Dan Kelas Kontrol

\begin{tabular}{|c|c|c|c|c|c|c|c|}
\hline \multirow{2}{*}{ Kelas } & \multirow{2}{*}{$X_{\text {maks }}$} & \multirow{2}{*}{$X_{\min }$} & \multicolumn{3}{|c|}{ Ukuran Tendensi Sentral } & \multicolumn{2}{|c|}{$\begin{array}{l}\text { Ukuran Variansi } \\
\text { Kelompok }\end{array}$} \\
\hline & & & $\overline{\boldsymbol{x}}$ & $\mathbf{M}_{\mathbf{e}}$ & $\mathbf{M}_{\mathbf{o}}$ & $\mathbf{R}$ & SD \\
\hline Eksperimen & 95 & 55 & 75,5 & 75 & 75 & 40 & 10.451 \\
\hline Kontrol & 85 & 45 & 68,5 & 75 & 75 & 40 & 11.738 \\
\hline
\end{tabular}

Berdasarkan Tabel 2. Dapat dilihat bahwa hasil belajar kognitif peserta didik pada kelas eksperimen mendapat nilai rata-rata 75,5 , median 75 , nilai yang sering muncul 75 sedangkan pada kelas kontrol memperoleh nilai rata-rata 68,8 dengan nilai median 75 modus 75 . Berdasarkan hal ini, ada perbedaan antara kelas eksperimen dan kelas kontrol.Kelas eksperimen memperoleh hasil belajar kognitif lebih tinggi dari kelas eksperimen.
Selanjutnya dilakukan analisis uji asumsi dengan uji normalitas hasil belajar kognitif peserta didik pada kelas eksperimen dengan hasil skor kelas eksperimen sebesar 75,5dengan $L_{\text {tabel }}=, 0,159$ dan $L_{\text {hitung }}=0,110$ hal ini menunjukan bahwa $\boldsymbol{L}_{\text {hitung }}<$ $\boldsymbol{L}_{\text {tabel }}$ sehingga dapat disimpulkan data berdistribusi normal. Dan kelas control adalah sekor kelas kontrol sebesar 
68,5dengan

$$
L_{\text {tabel }}=0,155 \text { dan }
$$

$\boldsymbol{L}_{\text {hitung }}=\mathbf{0 , 1 2 8 \mathrm { hal }}$ ini menunjukan bahwa $\boldsymbol{L}_{\text {hitung }}<\boldsymbol{L}_{\text {tabel }}$ sehingga dapat disimpulkan data berdistribusi normal.
Berikut hasil rekapitulasi perhitungan uji normalitas hasil belajar kognitif peserta didik pada kelas eksperimen dan kelas kontrol.

Tabel 3. Rangkuman Hasil Uji Normalitas Data Hasil Belajar Kognitif Peserta Didik

\begin{tabular}{clccc}
\hline No & \multicolumn{1}{c}{ Kelas } & $\boldsymbol{L}_{\text {hitung }}$ & $\boldsymbol{L}_{\text {tabel }}$ & Keputusan Uji \\
1 & Eksperimen & 0,110 & 0,159 & Normal \\
2 & Kontrol & 0,128 & 0,155 & Normal \\
\hline
\end{tabular}

Berdasarkan perhitungan hasil uji coba normalitas hasil belajar kognitif peserta didik pada kelas eksperimen dan kelas kontrol dengan taraf sigifikansi $\alpha=0,05$, diperolah bahwa nilai dari $L_{\text {hitung }}$ dari setiap kelompok kurang dari $L_{\text {tabel }}$ sehingga hipotesis nol dari setiap kelompok diterima. Dapat disimpulkan bahwa data yang diperoleh dari setiap kelompok berasal dari populasi yang berdistribusi normal.
Mengetahui apakah kedua skor memiliki karakter yang sama atau berbeda maka diperlukan uji F. Pengujian variansi ini yaitu membandingkan varians terbesar dan varians terkecil. Jika $F_{\text {hitung }} \leq$ $F_{\text {tabel }}\left(\sigma_{1}, \sigma_{2}\right)$ didapat dari distribusi dengan peluang $\frac{1}{2} \alpha$ sedangkan derajat kebebasan $\sigma_{1}\left(n_{1}-1\right)$ dan $\sigma_{2}\left(n_{2}-2\right)$ masing-masing sesuai dengan $d k$ pembilang dan $d k$ penyebut.Hasil pengujian varians dengan taraf signifikan $\alpha=0,05$ dapat dilihat pada Tabel 3.

Tabel 4. Hasil Uji Homogenitas

\begin{tabular}{ccccc}
\hline No & Kelompok & $\boldsymbol{x}^{2}{ }_{\text {tabel }}$ & $\boldsymbol{x}^{2}{ }_{\text {hitung }}$ & Keputusan Uji \\
1 & $\mathrm{~A}_{1} \mathrm{~A}_{2}$ & 3,841 & 0,389 & Homogen \\
\hline
\end{tabular}

Berdasarkan Tabel 4. Hasil perhitungan skor hasil belajar kognitif peserta didik diperoleh $\boldsymbol{x}^{2}{ }_{\text {hitung }}=$ 10,389dan $x^{2}$ tabel $=3,841$ Menunjukan bahwa $\boldsymbol{x}_{\text {hitung }}<\boldsymbol{x}^{2}{ }_{\text {tabel }}$ dengan hal ini dapat disimpulkan bahwa $H_{0}$ diterima atau sampel berasal dari populasi yang memiliki varians sama.
Berdasarkan data yang telah diperoleh, hasil uji prasyarat yaitu uji normalitas menunjukkan bahwa data pada setiap kelas berasal dari populasi yang berdistribusi normal dan memiliki varians yang homogen. Selanjutnya dilakukan uji hipotesis dengan menggunakan uji analisis variansi (ANAVA) dua jalan sel tak sama pada taraf signifikansi 0,05 .

Tabel 5. Rangkuman Analisis Variansi Dua Jalan Sel Tak Sama

\begin{tabular}{clllllcl}
\hline Sumber & \multicolumn{1}{c}{$\mathrm{JK}$} & $\mathrm{dK}$ & $\mathrm{RK}$ & $F_{\text {hitung }}$ & $F_{\text {tabel }}$ & $\mathrm{A}$ \\
Perlakuan (A) & 475.9734 & 1 & 475.9734 & 4.5682 & 4.016 & 0,05 \\
Kecerdasan (B) & 1989.0738 & 2 & 994.5369 & 9.5451 & 3.165 & 0,05 \\
Interaksi (AB) & 16.1518 & 2 & 8.0759 & 0.0775 & 3.165 & 0,05 \\
Galat & 5730.6140 & 55 & 104.1930 & - & - & - \\
Total & 8211.813 & 60 & - & - & - & - \\
\hline
\end{tabular}


Berdasarkan perhitungan pengujian analisis data dapat disimpulkan bahwa:

a. $\quad F_{a}=4,5682$ dan taraf signifikansi 0,05 diperoleh $F_{(0,05 ; 1 ; 55)}=$ 4,016sehingga $\mathrm{F}_{\mathrm{a}}>F_{(0,05 ; 1 ; 55)}$ yang menunjukkan bahwa $H_{0 A}$ ditolak berarti terdapat pengaruh model pembelajaran Quantum Teaching terhadap hasil belajar kognitif.

b. $\quad F_{b}=9,5451$ dan taraf signifikansi 0,05 diperoleh $F_{(0,05 ; 2 ; 55)}=3,165$ sehingga $\quad \mathrm{F}_{\mathrm{b}} \quad>F_{(0,05 ; 2 ; 55) \text { yang }}$ menunjukkan bahwa $H_{0 B}$ ditolak berarti terdapat pengaruh kecerdasan majemuk peserta didik terhadap hasil belajar kognitif.

c. $\quad \mathrm{F}_{\mathrm{ab}}=0,0775$ dan taraf signifikansi 0,05 diperoleh $F_{(0,05 ; 2 ; 55)}=$ 3,165 sehingga $\mathrm{F}_{\mathrm{ab}}<F_{(0,05 ; 2 ; 55)}$ yang menunjukkan bahwa $H_{0 A B}$ diterima berarti Tidak terdapat interaksi antara model pembelajaran Quantum Teachingdan kecerdasan majemuk siswa terhadap hasil belajar kognitif.

Berdasarkan ketiga hipotesis nol terdapat dua hipotesis nol yang di tolak, yaitu $\mathrm{H}_{\mathrm{OA}}$ dan $\mathrm{H}_{\mathrm{OB}}$.Hal ini menunjukkan bahwa terdapat perbedaan antara model pembelajaran dengan hasil belajar kognitif dan terdapat perbedaan antara peserta didik yang memiliki kecerdasan logis-matematis, interpersonal dan naturalis.Model pembelajaran yang dimiliki hanya 2 kategori maka untuk antar baris tak perlu dilakukan uji komparasi ganda.Sedangkan kecerdasan majemuk peserta didik memiliki 3 kategori, sehingga perlu dilakukan uji komparasi rerata antar kolom pada masing-masing kategori kecerdasan majemuk peserta didik untuk mengetahui kategori yang mempunyai perbedaan yang signifikan.Berikut adalah data hasil rerata marginal yang dapat dilihat pada Tabel 6.

Tabel 6. Rataan Marginal

\begin{tabular}{|c|c|c|c|c|}
\hline \multirow[b]{2}{*}{ Perlakuan $\left(A_{1}\right)$} & \multicolumn{3}{|c|}{ Pengkategorian Kecerdasan Majemuk $\left(B_{j}\right)$} & \multirow[b]{2}{*}{$\begin{array}{c}\text { Rataan } \\
\text { Marginal }\end{array}$} \\
\hline & $\begin{array}{l}\text { Logis- } \\
\text { Matematis } \\
\left(B_{1}\right)\end{array}$ & $\begin{array}{c}\text { Interpersonal } \\
\left(\mathrm{B}_{2}\right)\end{array}$ & Naturalis $\left(B_{3}\right)$ & \\
\hline $\begin{array}{l}\text { Model Pembelajaran Quantum } \\
\text { Teaching }\left(\mathrm{A}_{1}\right)\end{array}$ & 87.0000 & 70.8333 & 73.9474 & 77.2602 \\
\hline Metode Ceramah $\left(\mathrm{A}_{2}\right)$ & 80.0000 & 65.8333 & 66.0000 & 70.6111 \\
\hline Rataan Marginal & 83.5000 & 68.3333 & 69.9737 & \\
\hline
\end{tabular}

Berdasarkan rerata marginal pada Tabel 6.terlihat bahwa peserta didik yang mendapatkan perlakuan menggunakan model pembelajaran Quantum Teaching yaitu sebesar 77,2602 lebih besar dibandingkan rerata marginal yang menggunakan model konvensional yaitu sebesar 70,6111. Sehingga dapat disimpulkan bahwa pembelajaran matematika dengan menggunakan model pembelajaran Quantum Teaching lebih efektif dibandingkan pembelajaran matematika dengan model konvensional.
Perhitungan uji komparasi rerata antar kolom pada masing-masing kategori kecerdasan majemuk peserta didik dapat dilihat pada lampiran. Adapun rangkuman hasil uji komparasi rerata antar kolom pada masing-masing kategori kecerdasan majemuk peserta didik dengan metode Scheffe" (komparasi ganda antar kolom) dengan keterangan ( $\mu_{1}=$ hasil belajar kognitif peserta didik dengan kategori kecerdasan logis matematis), ( $\mu_{2}=$ hasil belajar kognitif peserta didik dengan kategori kecerdasan interpersonal), ( $\mu_{2}=$ hasil belajar kognitif 
Desimal, 1 (2), 2018 - 252

Ratna Pramudita

peserta didik dengan kategori kecerdasan

naturalis).

Tabel 7. Hasil Uji Komparasi Ganda Antar Kolom

\begin{tabular}{ccccc}
\hline No & Interaksi & $\boldsymbol{F}_{\text {hitung }}$ & $\boldsymbol{F}_{\text {tabel }}$ & Kesimpulan \\
1 & $\mu_{1}$ vs $\mu_{2}$ & 12,04 & 6,34 & $H_{0}$ ditolak \\
2 & $\mu_{1}$ vs $\mu_{3}$ & 13,98 & 6,34 & $H_{0}$ ditolak \\
3 & $\mu_{2}$ vs $\mu_{3}$ & 0,24 & 6,34 & $H_{0}$ diterima \\
\hline
\end{tabular}

Berdasarkan Tabel 7. maka dapat disimpulkan:

a. Hasil perhitungan menunjukkan $\mathrm{F}_{\text {hitung }}>\mathrm{F}_{\text {tabel }}$ dengannilai $\mathrm{F}_{\text {hitung }}=$ 12,04 dan $F_{\text {tabel }}=6,34$. Sehingga $\mathrm{H}_{0}$ ditolak, berarti terdapat perbedaan hasil belajar kognitif antara peserta didik yang memiliki kecerdasan logis-matematis dengan peserta didik yang memiliki kecerdasan interpersonal. Berdasarkan Tabel 6 reratahasil belajar kognitif peserta didik dengan kategori kecerdasan logis matematis, sebesar 83,50 lebih besar dibandingkan rerata hasil belajar kognitif peserta didik dengan kategori kecerdasan interpersonal, sebesar 68,33. Sehingga peserta didik dengan kategori kecerdasan logis-matematis memiliki hasil belajar kognitif lebih baik daripada peserta didik dengan kategori kecerdasan interpersonal.

b. Hasil perhitungan menunjukkan $F_{\text {hitung }}>\mathrm{F}_{\text {tabel }}$ dengannilai $\mathrm{F}_{\text {hitung }}=$ 13,98 dan $F_{\text {tabel }}=6,34$. Sehingga $\mathrm{H}_{0}$ ditolak, berarti terdapat perbedaan hasil belajar kognitif antara peserta didik yang memiliki kecerdasan logis-matematis dengan peserta didik yang memiliki kecerdasan naturalis. Berdasarkan Tabel 6 reratahasil belajar kognitif peserta didik dengan kategori kecerdasan logis matematis, sebesar 83,50 lebih besar dibandingkan rerata hasil belajar peserta didik dengan kategori kecerdasan naturalis, sebesar 69,97. Sehingga peserta didik dengan kategori kecerdasan logis matematis memiliki hasil belajar kognitif lebih baik daripada peserta didik dengan kategori kecerdasan naturalis.

c. Hasil perhitungan menunjukkan $F_{\text {hitung }}<F_{\text {tabeldengannilai }} F_{\text {hitung }}=$ 0,24 dan $F_{\text {tabel }}=6,34$. Sehingga $\mathrm{H}_{0}$ diterima, berarti tidak terdapat perbedaan hasil belajar kognitif yang signifikan antara peserta didik yang memiliki kecerdasan interpersonal dengan yang memiliki kecerdasan naturalis.

Hasil penelitian ini sama dengan hasil penelitian oleh (Amiluddin \& Sugiman, 2016; Mujib, 2016) bahwa model pembelajaran yang digunakan sangant berpengaruhterhadap hasil belajar peserta didik. Selain itu menurut Siregar \& Juliani (2014)bahwa model pembelajaran quantum teaching memberikan hasil belajar dan tingkat kecerdasan siswa lebih baik dari pada metode ceramah. Menurut (Danaryanti \& Julianti, 2014) model pembelajaran quantum teaching berpengaruh terhadap hasil belajar dan kemampuan komunikasi matemtematis. Selain itu berdasarkan penelitian Prabawanti (2015)model quantum teaching sangat mempengaruhi hasil belajar siswa.Selain itu menurut (Isnaini, Wigati, \& Oktari, 2016) dalam penelitiannya model pembelajaran quantum teaching dengan langkahlangkah TANDUR berpengaruh terhadap keterampilan proses pada materi sel (IPA). Menurut dalam penelitiannya memiliki efektivitas model quantum teaching berpengaruhterhadap hasil 
belajar ditinjau keterampilan berpikir kritis pada pembelajaran IPA dikelas $\mathrm{V}$ SD.

Selanjutnya hasil penelitian Abi Fadila (2014)didukung bahwa model pembelajaran yang tepat dalam pembelajaran matematika pada materi tertentu mampu meningkatkan kecederdasan majemuk siswa berdasarkan peningkatan peta fikiran siswa sehingga dengan hal itu peningkatan juga akan terjadi dalam koneksi pembelajaran matematika. Selain itu menurut (Sholikhah \& Budiyono, 2014) ecerdasan majemuk dengan hasil belajar memiliki hubungan yang sedang, kecerdasan yang bisa dikembangkan pada mata pelajaran IPA ialah kecerdasan logis-matematis, naturalis dan interpersonal. Selain itu menurut (Sholikhah \& Budiyono, 2014) dalam penelitiannya model pembelajaran kooperatif tipe group investigation dan NHT lebih efektif di bandingkan dengan model pembelajaran konvensional, siswa dengan kecerdasan logis-matematis lebih baik dari siswa yang memiliki kecerdasan interpersonal dan linguistik, tidak ada perbedaan yang signifikan antara kecerdasan interpersonal dengan linguistik. Selanjutnya penelitian yang dilakukan (Hariyati et al., 2013) dalam penelitiannya model pembelajaran kooperatif tipe (Team Assisted Individualization) TAI dan (Problem Based Learning) PBL berpengaruh pada prestasi belajar matematika, siswa dengan kecerdasan logis-matematis lebih baik dari siswa yang memiliki kecerdasan interpersonal dan linguistik, tidak ada perbedaan yang signifikan antara kecerdasan interpersonal dengan linguistik.

\section{SIMPULAN DAN SARAN}

Berdasarkan hasil peneltian yang telah dianalisis dan didukung oleh teori maka dapat disimpulkan terdapat pengaruh model quantum teachingterhadap hasil belajar kognitif peserta didik.Selanjutnya Terdapat perbedaan antara peserta didik yang memiliki kecerdasan logis-matematis dengan kecerdasan interpersonal dan naturalis terhadap hasil belajar kognitif, namun peserta didik yang memiliki kecerdasan interpersonal dengan naturalis tidak memiliki perbedaan terhadap hasil belajar kognitif.Tidak terdapat interaksi antara model pembelajaran dan kecerdasan peserta didik logis-matematis, interpersonal, dan naturalis terhadap hasil belajar kognitif peserta didik

Model pembelajaran Quantum Teachingdapat meningkatkan keterlibatan peserta didik dalam aktifitas pembelajaran.Oleh karena itu disarankan kepada pendidik untuk menerapkan model pembelajaran Quantum Teachingdalam pembelajaran matematika, sebagai alternatif dalam pembelajaran yang dapat meningkatkan hasil belajar kognitif matematika peserta didik.Bagi penelitian selanjutnya disarankan untuk melihat peningkatan setiap indikator hasil belajar kognitif dan kemampuan lainnya yang bisa diterapkan melalui model pembelajaran Quantum Teaching.

\section{DAFTAR PUSTAKA}

Amiluddin, R., \& Sugiman, S. (2016). Pengaruh Problem Posing dan PBL Terhadap Prestasi Belajar, dan Motivasi Belajar Mahasiswa Pendidikan Matematika. Jurnal Riset Pendidikan Matematika, 3(1), 100-108.

Bahri, A. (2010). Pengaruh Strategi Pembelajaran Reading Questioning and Answering (RQA) pada Perkuliahan Fisiologi Hewan terhadap Kesadaran Metakognitif, Keterampilan Metakognitif dan Hasil Belajar Kognitif Mhs. Jurusan Biologi FMIPA Universitas Negeri 
Makassar. (Tesis). DISERTASI dan TESIS Program Pascasarjana UM, $O(0)$.

Danaryanti, A., \& Julianti, J. (2014). Implementasi Model Pembelajaran Kooperatif Tipe The Power of Two dalam Pembelajaran Matematika pada Materi Bangun Ruang di Kelas VIII SMP. EDU-MAT, 2(2), 78-85.

Fadila, A. (2015). Eksperimentasi Model Pembelajaran Kooperatif Tipe Student Teams Achivement Division (STAD) dan Teams Game Tournament (TGT) dengan Pendekatan Kontekstual Terhadap Prestasi Belajar dan Aspek Afektif Matematika Siswa Ditinjau dari Kecerdasan Majemuk Siswa (PhD Thesis). Universitas Sebelas Maret.

Febriyanto, G. (2011). Upaya Meningkatkan Aktivitas dan Hasil Belajar Siswa dengan Menggunakan Metode Index Card Match pada Mata Pelajaran IPA Terhadap Siswa Kelas IV SD Negeri 2 Tanjungsari Rembang Tahun Ajaran 2011/2012 (PhD Thesis). Universitas Muhammadiyah Surakarta.

Hariyati, E., Mardiyana, M., \& Usodo, B. (2013). Efektivitas Model Pembelajaran Kooperatif Tipe Team Assisted Individualization (TAI) dan Problem Based Learning (PBI) pada Prestasi Belajar Matematika Ditinjau dari Multiple Intelligences Siswa SMP Kabupaten Lampung Timur Tahun Pelajaran 2012/2013. Jurnal Pembelajaran Matematika, 1(7), 52-60.

Husni, H., Kamaluddin, K., \& Kade, A. (2014). Hubungan antara Kecerdasan Majemuk dengan Hasil Belajar Fisika Siswa Kelas VII SMP Negeri di Kota Palu. Jurnal Pendidikan Fisika Tadulako Online (JPFT), 1(3), 32-39.
Ismail, Gani, A., \& Syahrun, N. (2015). Penerapan Strategi Mastery Learning untuk Meningkatkan Minat dan Hasil Belajar Materi Listrik Statis pada Siswa SMA N 1 Krueng Barona Jaya Aceh Besar. Jurnal Pendidikan Sains Indonesia, 3(1), 72-80.

Isnaini, M., Wigati, I., \& Oktari, R. (2016). Pengaruh Penggunaan Media Pembelajaran Torso Terhadap Hasil Belajar Siswa pada Materi Sistem Pencernaan pada Manusia di SMP Negeri 19 Palembang. Jurnal Biota, 2(1), 82-91.

Lamba, H. A. (2016). Pengaruh Pembelajaran Kooperatif Model STAD dan Gaya Kognitif Terhadap Hasil Belajar Fisika Siswa SMA. Jurnal Ilmu Pendidikan, 13(2), 269-277.

Mohiddin, D. P. (2016). Pengaruh Model Pembelajaran Quantum Teaching dan Kemampuan Berpikir Matematis Terhadap Hasil Belajar Siswa. Jurnal Technopreneur (JTech), 4(2), 90-93.

Mujib, M. (2016). Mengembangkan Kemampuan Berfikir Kritis Melalui Metode Pembelajaran Improve. AlJabar: Jurnal Pendidikan Matematika, 7(2), 167-180.

Ningsih, Y. L., Misdalina, M., \& Marhamah, M. (2017). Peningkatan Hasil Belajar dan Kemandirian Belajar Metode Statistika Melalui Pembelajaran Blended Learning. Al-Jabar: Jurnal Pendidikan Matematika, 8(2), 155-164.

Novalia, M. S. (2014). Olah Data Penelitian Pendidikan. Bandar Lampung: Anugrah Utama Rahaja.

Nurliani, N., Subarjah, H., \& Sujana, A. (2016). Pengaruh Model Pembelajaran Berbasis Masalah Terhadap Hasil Belajar Peserta Didik Pada Materi Peristiwa Alam. Jurnal Pena Ilmiah, 1(1), 981-990. 
Prabawanti, E. S. (2015). Penerapan Model Pembelajaran Quantum Teaching dengan Metode Diskusi Berbantuan Lembar Kerja Siswa (LKS) untuk Meningkatkan Hasil Belajar Materi Bentuk Pangkat dan Akar pada Siswa Kelas X. 6 Semester I SMA Negeri 2 Magetan Tahun Pelajaran 2013/2014. Jurnal Ilmiah Pendidikan Matematika, 3(2), 390-397.

Sari, Y. K., Susilowati, S. M. E., \& Ridlo, S. (2013). Efektivitas Penerapan Metode Quantum Teaching pada Pendekatan Jelajah Alam Sekitar (JAS) Berbasis Karakter dan Konservasi. Journal of Biology Education, 2(2), 96-105.

Sholikhah, O. H., \& Budiyono, B. (2014). Eksperimentasi Model Pembelajaran Kooperatif Tipe Group Investigation (GI) dan Numbered Heads Together (NHT) pada Materi Garis Singgung Lingkaran Ditinjau dari Kecerdasan Majemuk Siswa Kelas VIII SMP Negeri Se-Kota Madiun Tahun Ajaran 2013/2014. Jurnal Pembelajaran Matematika, 2(7), 88-96.

Siregar, I. H., \& Juliani, R. (2014). Pengaruh Model Pembelajaran Quantum Teaching Terhadap Hasil Belajar Siswa pada Materi Pokok Zat dan Wujudnya di Kelas VII Semester I Smp Negeri 3 Percut Sei Tuan T.P 2013/2014. INPAFI (Inovasi Pembelajaran Fisika), 2(2), 107-116.

Sudarman, S. W., \& Vahlia, I. (2016). Efektifitas Penggunaan Metode Pembelajaran Quantum Learning terhadap Kemampuan Pemahaman Konsep Matematis Mahasiswa. Al-Jabar: Jurnal Pendidikan Matematika, 7(2), 275282.

Widyastuti, R. (2015). Proses Berpikir Siswa dalam Menyelesaikan
Masalah Matematika berdasarkan Teori Polya ditinjau dari Adversity Quotient Tipe Climber. Al-Jabar: Jurnal Pendidikan Matematika, 6(2), 183-194.

Winaya, I. M. A. (2016). Pengaruh Model Quantum Teaching Terhadap Hasil Belajar Ditinjau dari Keterampilan Berpikir Kritis Siswa pada Pembelajaran IPA di Kelas V SD N. 1 Selan Bawak. Widya Accarya, 5(1), 201-213. 